\title{
安全な海上輸送の実現に向けて 独立行政法人海上技術安全研究所の取組み
}

\author{
海上技術安全研究所＼cjkstart谷澤克治，小田野直光
}

\begin{abstract}
海上技術安全研究所では，海上輸送の安全確保のための研究活動を精力的に実施している。 本稿では重点的に実施している研究課題として, 船体の構造強度基準の策定に関する研究, 衝 突・座礁の防止など操船に係わる安全性向上のための研究，復原性基準策定等の荒天波浪中を 航走する船舶の安全性向上のための研究，危険物・放射性物質等の海上輸送に係わる安全性向 上のための研究，海難事故再発防止に対する取組みなどを紹介する。
\end{abstract}

I .はじめに

我が国の輸出入貨物のうち，どの程度が船舶によって 海上輸送されているかご存知であろうか。平成 20 年の海 事レポートによると，実に $99.7 \%$ 海上輸送されてい る。海上輸送は食料やエネルギー・鉱物資源の輸入や自 動車等の工業製品の輸出に欠かせないものであり，国民 生活を支える生命線である。安全で安定的な海上輸送の 確保は四面を海に囲まれた我が国にとって最重要課題の ひとつであるといえよう。

ところが，船舶の重大海難事故が世界中で発生してお り，海上輸送の安全性はまだまだ十分とはいえない状況 にある。例えば，「ナホトカ号」事故(1997年)，「エリカ 号」事故(1999年)，「プレステージ号」事故 (2002年：第 1 図)では，いずれも船体折損から引き起こされた大規模 油流出が立て続けに起こり, 沿岸国に甚大な環境被害を 及ぼしたバルト海における RORO 客船「エストニア号」 の転覆事故 (1994年)では900人近くの人命が失われる大 惨事となった。国内においても，底引網漁船「第五龍寶 丸」の転覆事故 (2000年) では乗組員 14 人が行方不明にな るなど，漁船の転覆事故が後を絶たず毎年人命が失われ ている。また，ジェットフォイル旅客船「トッピー4」の 浮遊物との衝突事故 (2006年)では, 多数の旅客が腰椎圧 迫骨折，腰椎破裂骨折などの重傷を負っている。今年に 入ってからでも，野島崎沖で発生したイージス艦「あた ご」と漁船「清徳丸」との衝突事故 ( 2 月)で 2 名が行方不

Activities of National Maritime Research Institute to Create the Basis for the Maritime Safety Improvements: Katsuji TANIZAWA, Naoteru ODANO.

(2008年 10 月 6 日 受理)
明に，明石海峡付近で発生した貨物船やタンカーなど 3 隻が絡む衝突事故 ( 3 月)では，貨物船「ゴールドリー ダー」が沈没して 3 人が死亡し， 1 人が行方不明になっ ている。

以上に述べたように，海上輸送の安全性はまだまだ不 十分であり，海上輸送の安全確保は国民の命と財産を守 るために不可欠であるのみならず，海難事故に伴う油污 染等の環境被害を未然に防止する観点からも非常に重要 である。そこで，独立行政法人海上技術安全研究所（以 下，海技研)では，第 2 期中期計画の重点課題に「海上輸 送の安全確保」を設定して研究活動を展開している。本 稿では，主に安全確保の切り口で海技研の活動を紹介す るとともに，使用済核燃料等の危険物の海上輸送に関す る安全確保への取組みについても併せて紹介したい。

\section{II ．構造安全性基準}

船舶の荒天下での折損事故等を未然に防止するには，

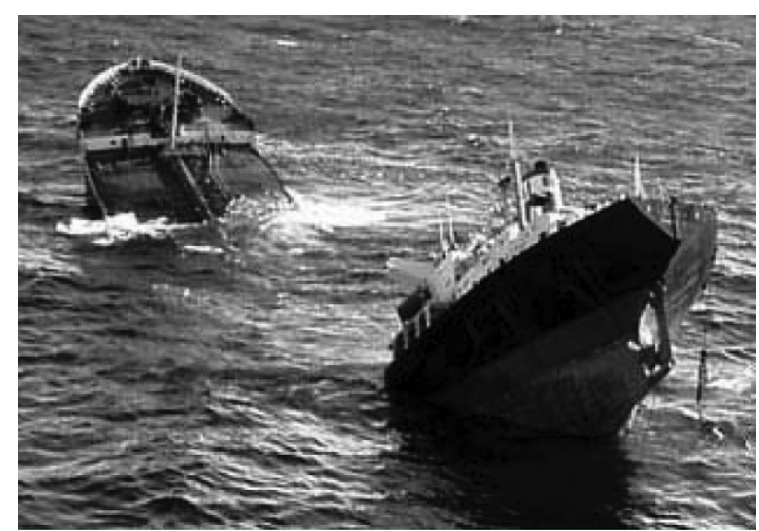

第 1 図 プレステージ号折損事故 (2002年) (事故報告書より) 
合理的な構造安全基準の整備が重要な対策の一つであ る。これまでも重大海難事故が発生するたびに国連の組 織 IMO (国際海事機関) が国際規則を整備し, 海上安全 の確保と海洋污染の防止に向けて中心的役割を担ってき た。しかし，近年の重大海難事故の多発を受けて，リス ク評価により均一な安全レベルを担保するより合理的な 安全基準の整備が求められている。海技研では以下に述 べる GBS の概念による合理的で体系的な船体構造強度 基準を提案すべく研究を実施している。

\section{1. 目的指向型構造安全基準}

目的指向型構造安全基準：GBS とは GOAL-BASED NEW SHIP CONSTRUCTION STANDARDS の略称 で, 船舶の構造設計・建造を対象にした基本的理念を構 築する基準である。これに対し，造船所が船舶の設計に 用いる構造設計規則は, 要求部材寸法を規定する仕様的 な規則であり，世界の主要な船級協会(我が国では日本 海事協会)がこれを定めている。GBS は船級協会が定め る詳細な仕様的規則を作成するための目標 (ゴール)や機 能要件等を規定した規則，すなわち規則作成のための規 則である。

IMO における GBS の審議では，国際的に整合性を確 保した構造設計規則を整備していくために，構造設計基 準の体系的整理に取り組んでいる。このような基準の体 系化は，すでに原子力など他分野でも取り組まれている ものである。IMO で現在合意されている基準体系は第2 図に示す 5 階層システムより構成されている。船級協会 等が策定する構造設計規則 (第 4 階層)の上位に，設計理 念 (ゴール (第 1 階層), 機能要件 (第 2 階層)) と適合性を 検証するスキーム (第 3 階層)を新たに確立する体系と なっている。第 3 階層の審議では事故をゼロに抑えるこ とが現実的に不可能であることを前提に，社会的に許容 できる安全レベルをどの程度に設定すべきかといった点 が審議されている。

海技研では安全レベルの設定にあたり，既存の設計規 則により設計・建造された船舶の安全レベルとの整合化 を図る，いわゆるルールキャリブレーションと呼ばれる 手法を採用し, 船体が中央で折損するような, 船体構造 上想定される最も危機的な状態の最終強度を対象に解析

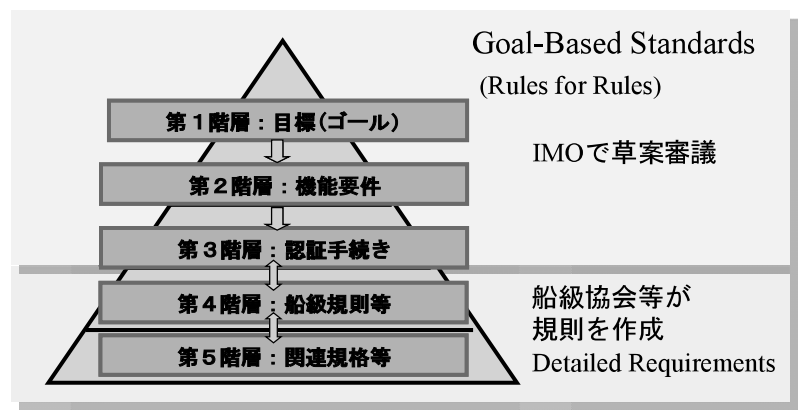

第 2 図 GBS 5 段階システム(基準の体系化)
調査に取り組むなど，構造信頼性解析を系統的に実施 ${ }^{1}$ するとともに，IMOにおける船舶が達成すべき安全レ ベルに関する国際的合意に向け，機動的に取り組んでい る。

\section{2. コンテナ船の大型化への対応}

世界的規模で海上輸送量が増大し続ける中，コンテナ 船の大型化が進み，「EMMA MAERSK号」のように積 載数が $11,000 \mathrm{TEU}$ (20フィートコンテナ換算の積載数) を超え, 全長が $400 \mathrm{~m}$ に迫る超大型コンテナ船が登場し ている。設計や安全基準の観点から見た場合，想定して いるコンテナ船は $6,000 \mathrm{TEU}$ 積み程度であるため，超 大型コンテナ船は基準の想定外となっている。また，こ れらを設計・建造するためには，板厚の増加あるいは鋼 材の高強度化が避けられないため, 使用実績のない板厚 および鋼材強度の構造部材に対する適切な評価を行った 上で新しい構造基準を設定することが不可欠となってい る。

これらの問題を合理的に解決するためには，鋼材強度 の確保，荷重と構造強度評価から工作の問題まで極めて 多岐にわたる検討が必要になる。とりわけ，構造部材ご との適切な材質選定や十分な構造強度の確保のために は, 構造強度評価の入力である荷重の推定精度の重要性 が従来以上に増してくることも明らかである。しかしな がら，大型化は船体剛性の相対的低下をもたらし，船体 が弾性梁として出会い波と同調して振動するスプリンギ ング現象が発生することも懸念される。また，大型化に 伴い船首船側が大きく張り出すといった船型上の特徴か ら，荒天中では波高に対する船体応答ならびに波浪荷重 の非線形性が顕著になってくる。

海技研ではこれら非線形影響や船体弾性影響を加味し た 6 自由度の船体運動/波浪荷重計算法を開発した ${ }^{2)} 。 6$ 自由度に対応できることから，斜め波中で船体に作用す る据りモーメントやホイッピング(波が船首部を吒くス ラミングという現象に伴う船体振動応答)を計算するこ とも可能である。

\section{III. 衝突・座礁防止}

海運を取り巻く状況は大きく変化しつつある。現在, 他の交通モードと同様に，乗組員の削減が進められてい るほか, 内航海運においては船員の高齢化が進み, 外航 海運においては外国人船員が増加した。これにより船員 の負担が増え，スキル維持も困難となり，ヒューマンエ ラーによる海難事故の発生が後を絶たない。一方，船舶 の大型化，高速化，海域の輻輳化が進んだことにより， 衝突・座礁事故に対する潜在的危険も増大するととも に，1回の事故の影響が大きくなっている。

このような状況に対応するため，優秀な船員の育成確 
保のほか，経験の少ない船員による安全な航行を実現す る，単純でわかり易い航海支援システムの開発が課題と なっている。まず，船舶の自律的航行機能の向上には， (1)電子海図表示や衝突・座礁警報機能等による状況認識 支援，(2)衝突危険状況表示や電子海図上への避険線 ( 入 ると危険な領域を示す線) 表示等による航行判断支援, (3)設定航路上を自動航行させるトラックパイロット等に よる操船支援の向上等が挙げられる。また，陸上から船 舶への航行支援機能の向上には，(4)海上交通センターに よる海域監視・管制，航行関連情報の提供，(5)船上機器 モニタリングなどによる陸上からの船舶管理等が挙げら れる。海技研では，これらの支援技術に関する研究を通 じて，関連国際規則・国際標準の策定支援，新しい航海 支援システムの提案を行い，環境変化に伴う諸問題に対 応している。また，以下に述べる e-Navigation 構想に も積極的に参画し，海上交通の ICT (情報通信技術) 化 を推進している。

\section{1. $\mathrm{e}^{- \text {Navigation }}$}

海上輸送に扔ける運航システムの電子化・情報化は他 の交通モードと比べて大きく遅れている。このため, IMO では海上安全委員会の下部組織である航行安全小 委員会 (NAV 小委員会) を軸に，情報通信技術を中心と した技術革新を総合的に反映させた $\mathrm{e}-\mathrm{Navigation} の$ 戦 略構築および関連サービスの導入作業を行っており, 海 上輸送の安全性および効率の向上，環境保護，保安を目 的に，新旧システムを有機的に活用した新しいサービス の提供を目指している。現在，e-Navigation 構想の状 況は，2008年でその戦略策定を終え，2009年度から 4 年計画で具体的なサービスの導入計画の検討に入る。

海技研は，海難分析から必要となるサービスを抽出す るとともに，サービス構築のためのロードマップを航行 安全小委員会に提案するなど, e-Navigation 戦略構築 に積極的に係わってきた。導入計画の検討においても積 極的に参画し，e-Navigation 関連サービス実現を目指 于 $^{3)}$ 。

\section{2. 新しい航海機器の開発・評価}

海技研では，自律的航行機能の向上を目的に，状況認 識，航行判断，操船支援の各機能を対象にして各種の航 海機器の開発を行っており, 操船者の最も重要としてい る目視情報にマッチする形で情報提供を行う目視認識支 援装置や先進航行安全支援システム (INT-NAV)の開発 を行った。また，現在，遭遇船舶との航行意思踈通を支

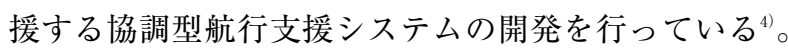
協調型航行支援システムは，自動船舶識別装置(AIS)を 利用し，遭遇船舶間で避航方法を矢印等でレーダ画面上 に重冨表示するものである。表示例を第 3 図に示す。こ れにより従来のVHF 無線より容易に意思疎通が行える

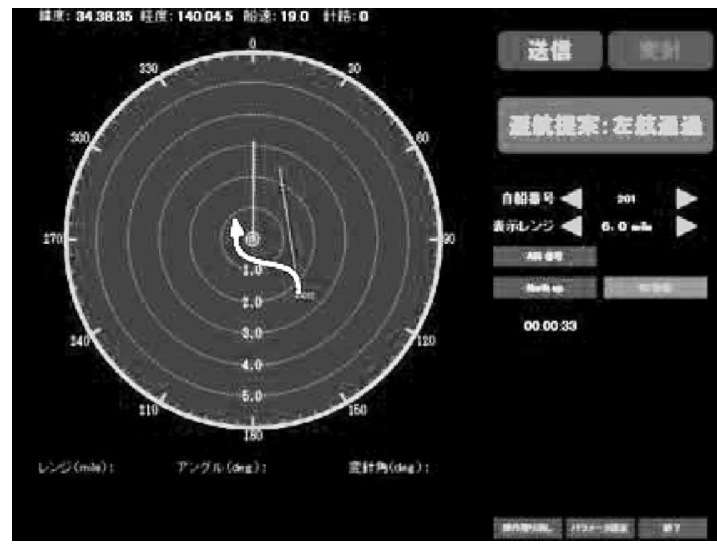

第 3 図 協調型航行支援システムの表示例

ほか，言葉の障壁や誤認等の発生を低く抑えることがで きると期待されている。

\section{N ．転覆事故防止}

転覆事故に対する安全性を確保するためには，十分な 復原性能を保持するとともに，適切な操船・運航を行う 必要がある。復原性能に関しては，国内規則である船舶 復原性規則および国際規則である IMO の非損傷時復原 性コード(ISコード)に扮いて基準值が定められてお り，規則が適用される船舶に関しては一定以上の復原性 能が確保されている。またIMO においては，転覆に至 る危険な状況を避けるための操船ガイダンスも定められ ている。以下，最近の IMO における復原性基準の検討 動向と海技研の取組みについて紹介する。

IMO では，1998年に北太平洋上において発生したコ ンテナ船のパラメトリック横摇(コンテナ船などのス マートな船体形状を有する船が向波や追波中を航走する 際に発生する大振幅横摇で，1 波ごとにブランコをこぐ ように横摇角が増加し，大振幅に至るのが特徴）に伴う コンテナ流出事故等を契機に，2002年から IS コードの 改正が審議されてきた。その結果，短期的な課題とされ た従来非強制の勧告であった IS コードの一部強制化が 昨年度の会合で合意され，現在，2010年 7 月発効予定で 条約の改正手続きが進められている。

一方，長期的な課題とされた性能要件化された復原性 基準の策定に向けた検討が昨年より本格的に開始され， 今年度の会合では，新世代非損傷時復原性基準としてそ の基本的な枠組みが合意され，2012年完了を目標に検討 を進めることとなった。

新世代非損傷時復原性基準は，現行の IS コードで安 全性が十分に担保されていない，機関故障時を想定した 操船不能状態の復原性, 復原力変動問題(パラメトリッ ク横摇，追波中復原力減少)，操縦性関連問題(ブローチ ング)の 3 つの危険モードに関して策定されるものであ り，危険性の有無を簡易に判定する基準 (第 1 段階基準) と数值計算を用いたより詳細な復原性能の直接評価基準 


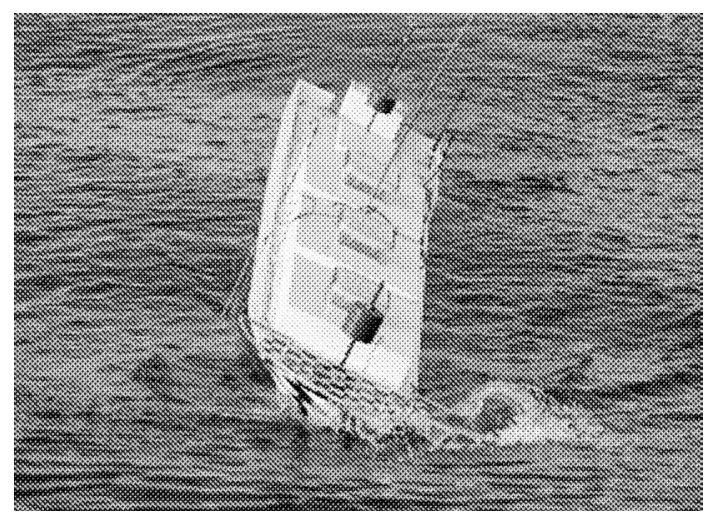

第 4 図 パラメトリック横摇の水槽実験

(第 2 段階基準)で構成される。

このような IMO に抢ける審議に対応するため，海技 研では IS コードの強制化の際に導入された一部基準の 代替評価のための標準模型試験方法を提案し，その検証 を行うとともに, 数值計算による復原性能の評価手法(操 船不能状態の転覆確率計算, パラメトリック横摇のシ ミュレーション計算)の検討を行っている。

特に，パラメトリック横摇に関しては，波浪中におけ る復原力変動に起因することから, 現象把握のための自 由航走模型を用いた実験 ${ }^{5}$ に加えて，復原力変動量を計 測する模型実験も行っており，シミュレーション計算の 検証等に活用している。(第 4 図)

\section{$\mathrm{V}$ ．危険物・放射性物質の海上輸送}

我が国の経済活動上，一般に危険物と呼ばれるガソリ ン，硫酸，火薬等の輸送は不可欠である。基準に適合し た容器に入れ，一般貨物船やコンテナ船で，あるいはケ ミカルタンカー, LPG 船, LNG 船に直接搭載すること により，危険物は大量に海上輸送されているのが現状で ある。また，原子力発電に関しては，新燃料(集合体お よび粉末)，使用済燃料，低レベル・高レベル放射性廃 棄物等が海上輸送されており，核燃料サイクルを支える うえで重要な役割を果たしている。

危険物輸送の安全確保は, 国際基準に基づき, 容器, 表示等の運送要件および船舶の構造, 設備等の技術基準 が国内法令で定められているとともに，危険物を輸送す る船舶に対して輸送前の検查や立入検查を行い，海上輸 送時の事故防止対策を行っている。

海技研に抢いては，放射性物質の海上輸送に係る研究 として，放射線遮蔽および放射線計測技術を中心に研究 を実施してきた。放射性物質の輸送はこれまでに安全の 実績を積み重ねてきているが，今後，国際的に放射性物 質輸送のセキュリティ強化が図られていくこと，国内で は，原子炉の廃止措置に伴う放射性解体廃棄物が大量に 海上輸送されることが予想されることから，海技研で は，放射性物質の安全輸送を支える基盤的な研究を従来
よりも幅広く実施しているところである。最近では，海 上輸送事故時の環境影響評価システムの構築，輸送のリ スク評価に関する研究，テロ等の不法行為に対する船舶 の保安向上に関する研究に取り組んでおり，本稿では近 年，重点的に取り組んでいる研究の主要な成果を紹介す る。

\section{1. 輸送容器の遮蔽安全評価に用いられるデータ および手法に関する研究}

我が国では，使用済燃料輸送容器の設計承認等の安全 審査に抢ける遮蔽安全評価には，離散座標法による輸送 計算コード ( 1 次元用：ANISN，2 次元用：DOT)が主 に使用されている。これらの輸送計算コードには中性 子・ガンマ線断面積セットが必要となるが，従来より米 国の評価済核データライブラリー ENDF/B-II に基づく DLC 23/CASK が広く用いられている。この断面積セッ 卜は1973年に作成されたものであり，特定の条件では計 算精度に問題があることがわかっており，最新の核デー タライブラリーに基づくデータセットが望まれている。 すでに，最新の評価済核デー夕である JENDL-3.3に基 づく, 輸送容器遮蔽評価用断面積セット SFCX-J 33が 開発されており，海技研では，1 次元平板体系および輸 送容器モックアップ体系において ${ }^{252} \mathrm{Cf}$ 線源を用いたベン チマーク実験を行い，新しい断面積セットSFCX-J 33 の検証を行った。ベンチマーク実験の結果と SFCX-J 33 を用いた解析結果はよく一致しており，SFCX-J 33は輸 送容器体系において十分な精度を有することを確認し た ${ }^{6}$ 。今後，輸送容器設計のみならず，幅広い分野での 活用が期待される。

また，放射線遮蔽解析の分野では，計算機の性能向上 に伴い，モンテカルロ法が広く使用されるようになって いる。上述のように，現在，輸送容器の安全審査におい ては輸送計算コードが使用されているが，2次元のモデ ル化をしているために，種々の安全裕度を見込んだ評価 をしているのが現状である。近年，炬心の高燃焼度化が 進んでおり， 2 次元モデルによる評価の結果を用いた場 合には，実際には輸送可能なまでに使用済燃料が泠却さ れているにもかかわらず，より長期間の冷却が求められ ることになる。そのため，海技研では，モデル化の䛊差 がほとんどないモンテカルロ法を輸送容器の安全審査の 遮蔽安全評価に適用可能であることを検証するためのべ ンチマーク実験を，モックアップ模型や実機輸送容器を 使用して実施している。これらの実験と解析を比較する ことにより，モンテカルロ法を用いる際に考慮すべき安 全裕度を明らかにするとともに，モンテカルロ法による 輸送容器の遮蔽解析手法のガイドラインを作成すること を目標としている。これらの研究成果は，高燃焼度使用 済燃料の効率的な輸送と最新の科学的知見に基づく合理 的な安全審査に資するものと期待される。 
2. 海上輸送事故時の環境影響評価システムの 構築

平成11年のウラン加工工場での臨界事故を契機に，平 成12年に原子力災害対策特別措置法が施行され，放射性 物質の輸送についても原子力災害としての対応が求めら れることになった。そのため, 海技研では, 国土交通省 からの受託研究として, 放射性物資の海上輸送時に事故

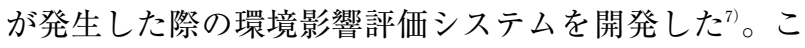
のシステムは，平成17年度より，国の核燃料物質等の海 上輸送時の災害対応に組み込まれており，事故時におい て，海技研が運用する体制が構築されている。海技研に おいては，短時間で，環境影響評価を実施し，国土交通 省がとる事故対策措置を迅速かつ的確に支援することが 求められている。

開発した環境影響評価システムの概念を第 5 図に示 す。システムは, 気象・海象等のデータベースのほか, 大気拡散解析, 海洋拡散解析, 船内被ばく線量評価解析 のための計算プログラムで構成されている。システムは 逐次，シミュレーションプログラムのさらなる高度化を 図っており，大気拡散解析では，港湾付近での事故を想 定し，陸上地形並びに海上および地上の大気の相互作用 を考慮できるよう改良するとともに，海洋拡散解析で
は，海流の流速・流向予測デー夕を活用した高精度で高 速な解析システムを構築中である。これらの成果は，事 故時の環境影響評価のみならず，テロ等の不法行為が発 生した際の環境影響評価にも活用されることが期待され る。

\section{VI．海難事故解析センターの開設}

最後に，海技研が 9 月 1 日に開設した「海難事故解析 センター」を紹介して本稿を締めくくりたい。

海難事故に際しては，客観的かつ定量的な事故情報を 迅速に収集するとともに，必要に応じて事故再現実験を 行い事故シナリオを検証し，事故原因を解明することが 再発防止策を立案する上で大変重要である。2008年10月 に国土交通省に運輸安全委員会が設置されたことを受 け，海技研では海難事故解析センターを開設し，重大海 難事故に対して即応体制を整えた。本センターは，事故 情報収集，事故解析，情報発信の機能を担っており，重 大海難事故発生に際しては，まず，センター長，副セン 夕一長，上級海難分析研究員等からなる情報分析会議を 招集し，迅速な情報発信を行うために必要は対応方針を 議決する。さらに，詳細解析が必要な場合には，第 6 図

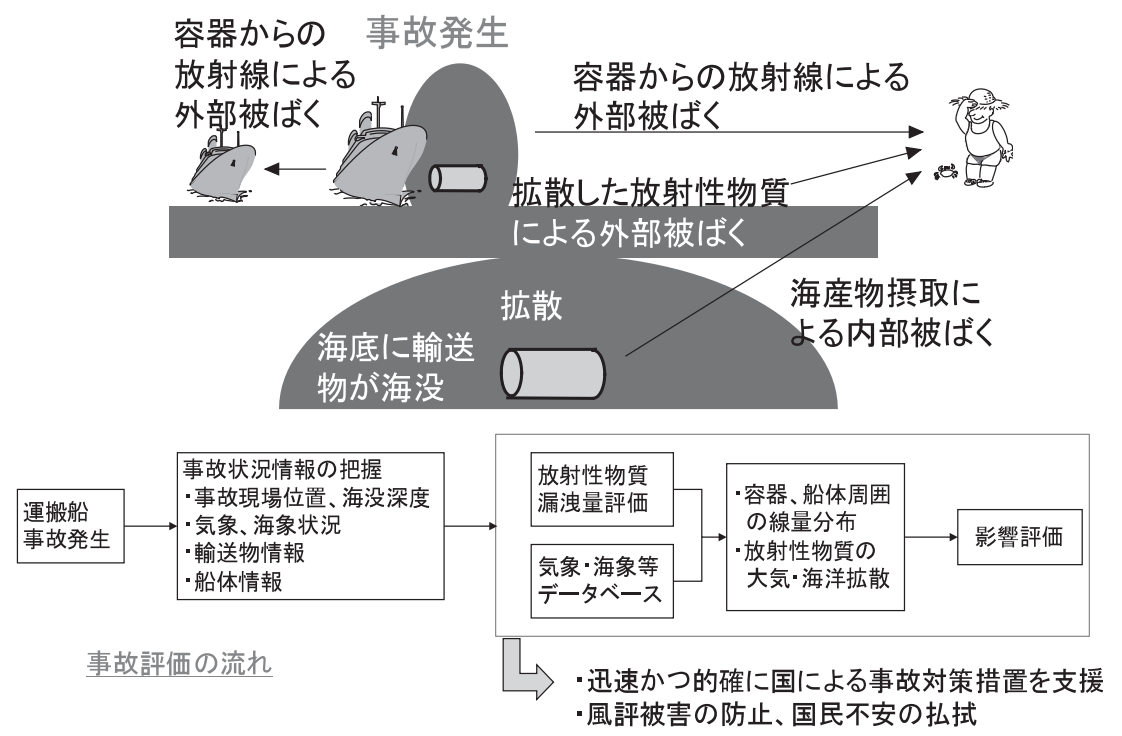

第 5 図 事故評価システムの概念

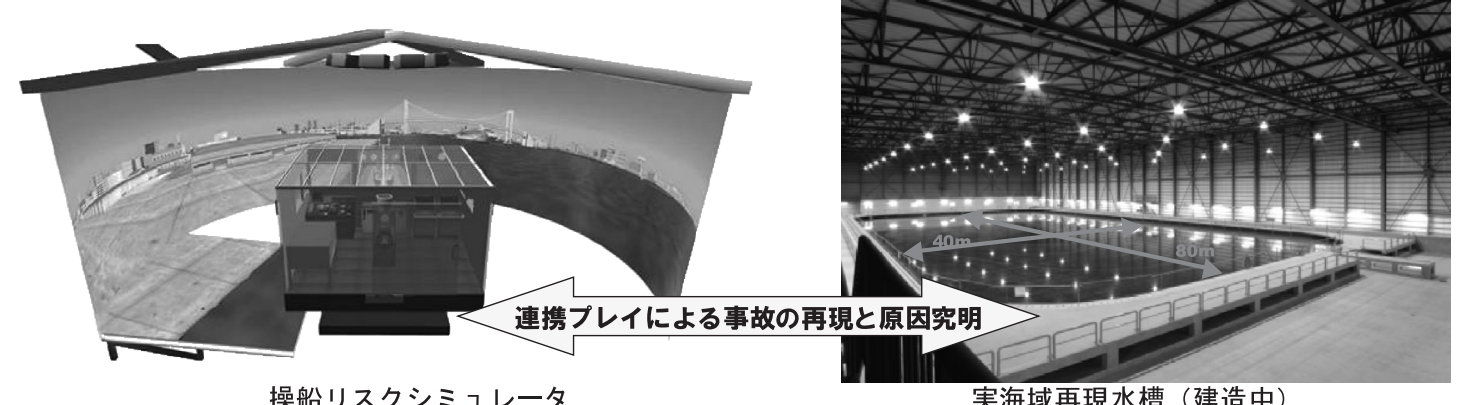

第 6 図 海難事故解析に活用される海技研の主要施設 
に示す主要施設等を活用し，事故再現や各種状況のシ ミュレーションを行うことにより，国等における再発防 止対策の立案等への支援を行っていく計画である。

\section{一参 考 資 料一}

1）平方勝, 他, “船舶の構造信頼性評価についての技術的課 題”, 日本船舶海洋工学会講演会論文集, 第 6 号, (2008).

2) Y. Ogawa, et. al., "The effect of a bow flare shape on the water impact pressure", Int. J. Offshore Polar Eng. (IJOPE), 16[2], 112-117(2005).

3）今津隼馬, 他, “航海情報の統合と表示に関する研究”, 日本航海学会論文集, 109, 133-140(2003).

4）南真紀子, 他, “AIS を用いた協調型航行支援システム の検討”, 日本航海学会論文集, $120(2009)$, 掲載予定.

5) H. Taguchi, S. Ishida, H. Sawada, M. Minami. “Model Experiment on Parametric Rolling of a Post-Panamax Containership in Head Waves", Proc. 9 th Int. Conf. on Stability of Ships and Ocean Vehicles, Vol. 1, p.147-156 (2006).

6）大西世紀，他， “ ${ }^{252} \mathrm{Cf}$ 核分裂中性子源を用いた遮へい透
過実験及び二次元離散座標計算コードによる輸送容器評 価用断面積セット SFCX-J 33の適用性に関する研究”, 海上技術安全研報，7[3]，1-20，(2007).

7) N. Odano, et al., "Development of Supporting System for Emergency Response to Maritime Transport Accidents involving Radioactive Material”, PATRAM 2004, (2004).

著者紹介

谷澤克治(たにざわ・かつじ)

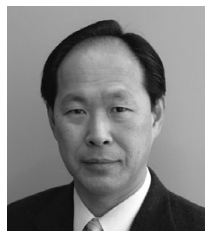

海上技術安全研究所

(専門分野)船舶工学，耐航性能，波浪荷重

小田野直光 (おだの・なおてる)

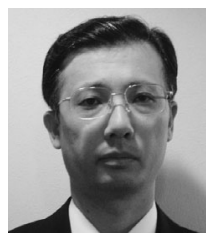

海上技術安全研究所

(専門分野)放射線工学，放射性物質輸送工 学

\section{$\square$ 目安箱への投書}

2005 年 10 月

日本原子力学会編集委員会

編集委員会は，読者・会員・投稿者・査読委員等からのご意見，ご提案を頂き，よりよい学会誌・論文誌編集活動を 目指す心゙く，意見空口「目安箱」を設けております。

・学会誌・論文誌の企画, 編集, 掲載記事・論文に関すること

・論文査読方針・審査方針およびシステムに関すること*

・新刊図書の書評の推薦

などについてのご意見・ご要望がございましたら，学会ホームページ http://wwwsoc.nii.ac.jp/aesj/publication/meyasu.html または E-mail（宛先 aesj2005meyasu@aesj.or.jp）にてお寄せ下さい。編集委員会にて検討後，担当編集委員より回答さ せていただきます。

学会誌，論文誌の編集活動への皆様の積極的なご参加をお願いいたします。

*個々の査読コメント等に関するお問合せ，ご意見等については受け付けかねますのでご了承下さい。 